\title{
Emerging Economies in East Asia: Are they Safe from Future Crises?
}

\author{
Yung Chul Park and Charles Wyplosz
}

\begin{abstract}
1 Introduction
The 1997 Asian financial crisis represents a watershed in East Asia's economic history. The end of the East Asian economic miracle has ushered in a long and painful period of economic reform and restructuring. It taught the crisis-hit countries a lesson that structural weaknesses of the financial system exacerbate a crisis when it occurs, though they may not necessarily trigger it. Indeed the crises left little doubt that the cumulative effect of financial imbalances could cause serious disruptions to the economy and interfere with real sector development. As part of their efforts to build resilience to external shocks, most of the East Asian countries including the crisis-hit ones have voluntarily or under external pressure, increased the pace and scope of domestic financial reform to liberalise and open their financial markets and also to improve soundness, corporate governance and risk management at financial institutions.
\end{abstract}

The reform efforts have been complemented by an accumulation of large foreign exchange reserves as self-insurance and the last line of defence against crises. Apparently these countries believe that financial reform alone will not ensure financial stability and safeguard against future crises. The 1997 financial turmoil has also served as a catalyst for building a region wide defence system against future crises as well as for deepening financial market and monetary integration. This movement has culminated in the institutionalisation of two regional initiatives: the Chiang Mai Initiative (CMI) and Asian Bond Market Development Initiative (ABMI).

Ten years have elapsed since the East Asian economies embarked on economic restructuring and institutional reform in 1997. The period may be long enough to allow an evaluation of the effects of the overall reform on efficiency and stability of the financial system. Most of the studies on the Asian crisis divide the causes of the crisis into three categories. The first category consists mostly of misguided macroeconomic policies that resulted in deterioration of the current account, which in turn provoked large capital outflows. They include the exchange rate policy that kept the currencies overvalued, premature and disorderly capital account liberalisation that induced a massive increase in capital inflows during the first half of the 1990s, much of which were speculative, and loose monetary policy that set off and fuelled asset inflation and bloating of real estate bubbles. The second category of the causes comprises inefficiencies and structural weaknesses of the financial sector. Some of the vulnerabilities in this category were a large overhang of loans for real estate financing, currency and term mismatches in the balance sheets, the absence of risk management, poor governance and lack of transparency at financial institutions including commercial banks. The third category refers to institutional weaknesses in governance in such dimensions as accountability, government effectiveness, political stability, quality of regulatory control, the rule of law and corruption as documented by a series of studies by Kaufmann et al. (2006).

The purpose of this article is to analyse in terms of statistical and other information available, whether East Asia in general and the crisis-affected countries in particular have been successful in improving policies, institutions and governance. On the basis of this evaluation, this study will assess whether and to what extent these countries will be able to withstand external shocks that may trigger a financial crisis.

Section 2 analyses potential macroeconomic vulnerabilities that may increase the probability of provoking a crisis. Section 3 is devoted to a review of financial and institutional reform the crisis-affected 


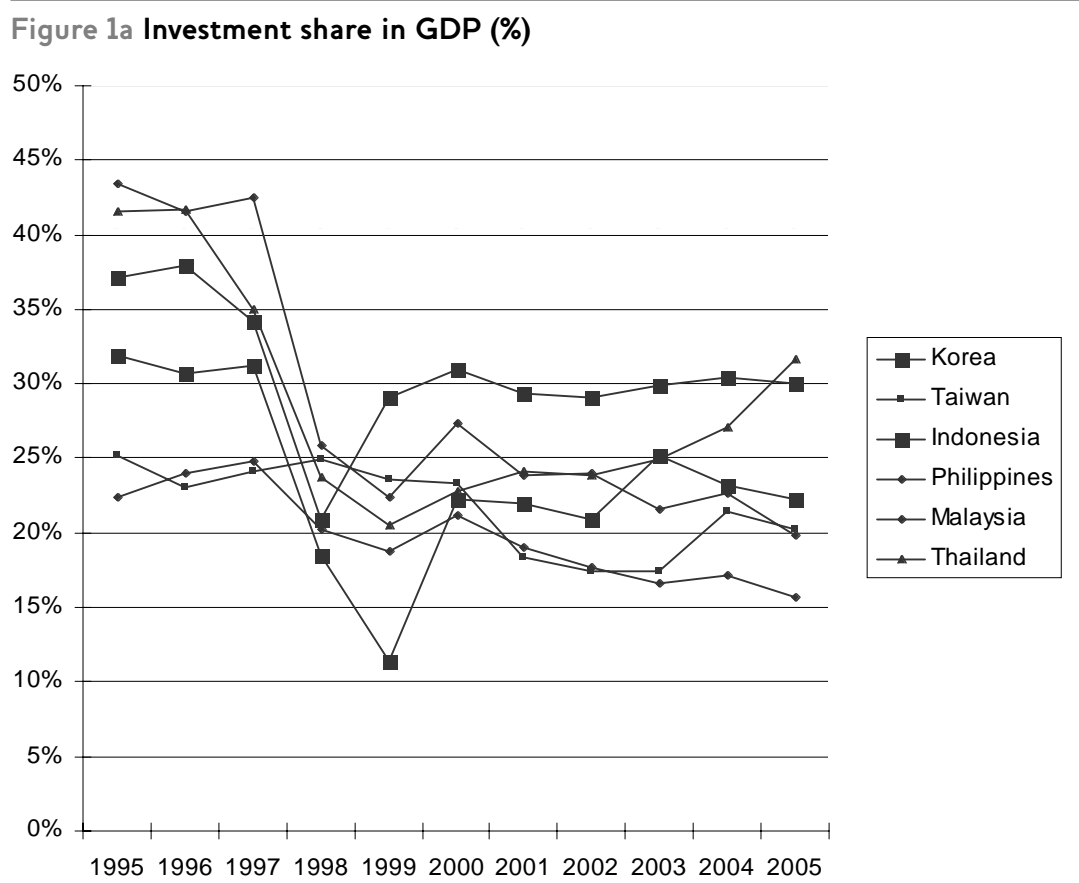

Source ADB Key Indicators (2006).

Figure 1b Saving share in GDP (\%)

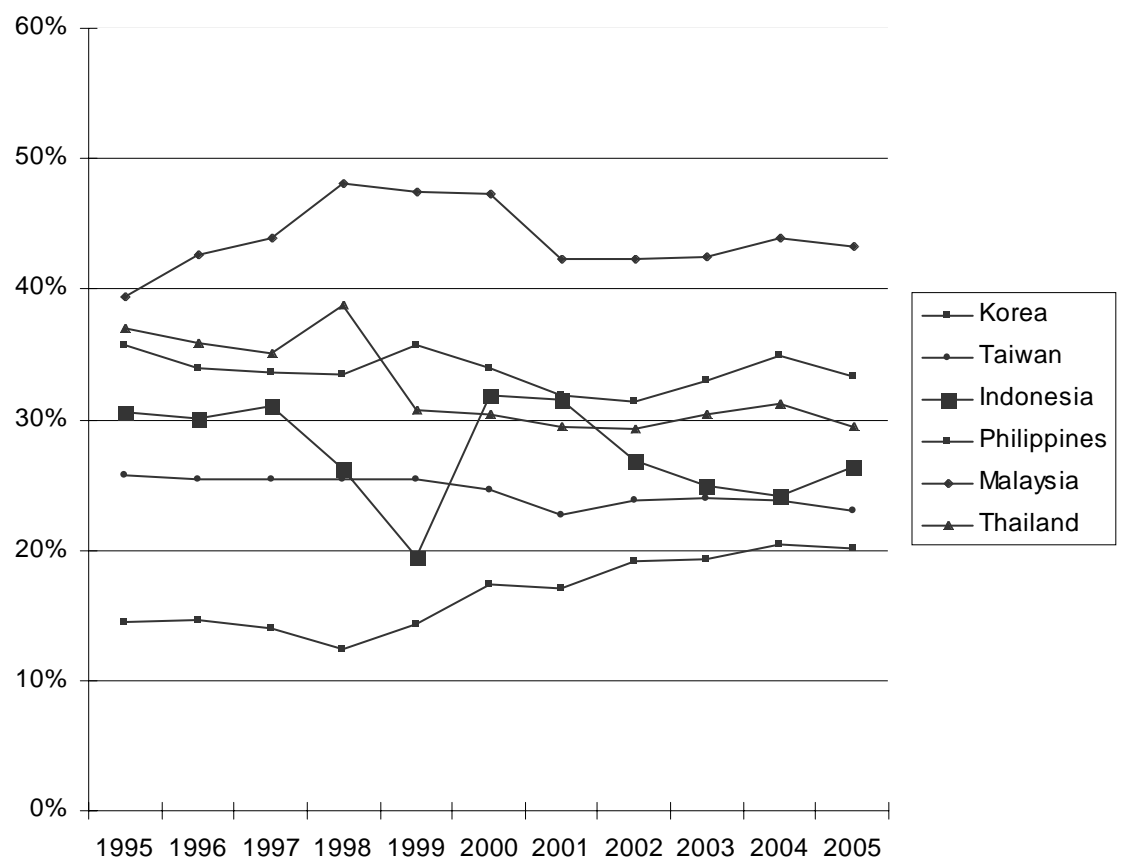

Source ADB Key Indicators (2006).

8 Park and Wyplosz Emerging Economies in East Asia: Are they Safe from Future Crises? 
Table 1 Current account surpluses of ten East Asian economies

\begin{tabular}{|c|c|c|c|c|c|c|c|c|c|}
\hline Country & 1999 & 2000 & 2001 & 2002 & 2003 & 2004 & 2005 & $2006^{p}$ & Cumulative to 2006 \\
\hline Japan & 114.6 & 119.7 & 87.8 & 112.5 & 136.2 & 172.1 & 165.8 & 168.3 & 1076.9 \\
\hline$\%$ of total & 51.7 & 58.7 & 50.4 & 49.2 & 45.9 & 48.3 & 22.6 & 41.5 & 41.1 \\
\hline$\%$ of GDP & 2.6 & 2.5 & 2.1 & 2.8 & 3.2 & 3.7 & 3.7 & 3.9 & \\
\hline \multirow[t]{3}{*}{ China } & 21.1 & 20.5 & 17.4 & 35.4 & 45.9 & 68.7 & 160.8 & 160.8 & 530.6 \\
\hline & 9.5 & 10.1 & 10.0 & 15.5 & 15.5 & 19.3 & 22.0 & 39.6 & 20.3 \\
\hline & 1.9 & 1.7 & 1.3 & 2.4 & 2.8 & 3.6 & 7.2 & 6.1 & \\
\hline \multirow[t]{3}{*}{ Korea \& Taiwan } & 32.9 & 21.2 & 26.3 & 31.0 & 41.2 & 46.7 & 32.6 & 24.0 & 255.9 \\
\hline & 14.9 & 10.4 & 15.1 & 13.6 & 13.9 & 13.1 & 4.5 & 5.9 & 9.8 \\
\hline & 4.5 & 2.5 & 3.4 & 3.7 & 4.5 & 4.7 & 2.9 & 1.9 & \\
\hline Hong Kong & 25.1 & 18.9 & 24.2 & 28.1 & 43.5 & 43.6 & 353.6 & 20.2 & 557.2 \\
\hline \multirow[t]{2}{*}{ \& Singapore } & 11.3 & 9.3 & 13.9 & 12.3 & 14.6 & 12.2 & 48.3 & 5.0 & 21.3 \\
\hline & 10.3 & 7.3 & 9.6 & 11.2 & 17.4 & 16.0 & 119.9 & 6.3 & \\
\hline \multirow[t]{3}{*}{ ASEAN 4} & 27.9 & 23.6 & 18.6 & 21.7 & 30.0 & 24.9 & 19.1 & 32.7 & 198.7 \\
\hline & 12.6 & 11.6 & 10.7 & 9.5 & 10.1 & 7.0 & 2.6 & 8.1 & 7.6 \\
\hline & 6.7 & 5.2 & 4.2 & 4.4 & 5.3 & 4.0 & 2.8 & 3.9 & \\
\hline Total & 221.7 & 203.8 & 174.3 & 228.8 & 296.8 & 355.9 & 732.0 & 406.0 & 2619.2 \\
\hline
\end{tabular}

Source IMF Intenational Financial Statistics, World Economic Outlook 2006 (IMF 2006d); The Economist 3 January 2007 for 2006 estimates.

countries have made and its contribution to financial stability since the crisis. Section 4 highlights some of the systemic risks that may destabilise financial markets of some of East Asia's emerging market economies (EMs). Here we note the financial weaknesses of both Indonesia and the Philippines as a potential source of financial turbulence that can be contagious. The other sources of financial distress are real asset inflation, which appears to be accelerating in some parts of East Asia and the fall of the US dollar. Section 5 examines the rationale of holding large amounts of reserves as a precautionary measure of warding off crises. Conclusions are in the final section.

\section{Macroeconomic vulnerabilities and crisis prevention}

The recovery of the crisis-affected countries was much faster than expected and in comparison with previous similar crises elsewhere. To some extent, Indonesia was an exception. By the second-quarter of 1998, stability had returned to financial and foreign exchange markets, the current account started registering a surplus and growth resumed. The major factor that helped break these countries out of a relatively short-lived recession was a surge in exports induced by large currency depreciation. Since then these countries have grown, on average, more than 5 per cent per year, mostly on the back of robust export expansion. Household consumption has been stagnant. From mid-2005 through mid2006, investment spending actually fell in three of those four-quarters in the Philippines, Thailand, and Taiwan, and in two out of four-quarters in Indonesia.

With few exceptions, all macroeconomic indicators are benign, as they mostly were when the crisis hit nearly a decade ago. Except for Indonesia and the Philippines, inflation is below 5 per cent, sometimes much lower. Except in a mild way, Malaysia budget balances are close to balance or in surplus and public debts are low except in the Philippines. Price stability is not just the result of conservative monetary and fiscal policies; it reflects stability of both wage growth and the prices of imported goods and services.

While the macroeconomic situation is generally reassuring, there might exist some more subtle vulnerabilities. The major source of growth continues to be exports, which have been increasing at around 20 per cent annually since the crisis. Domestic 


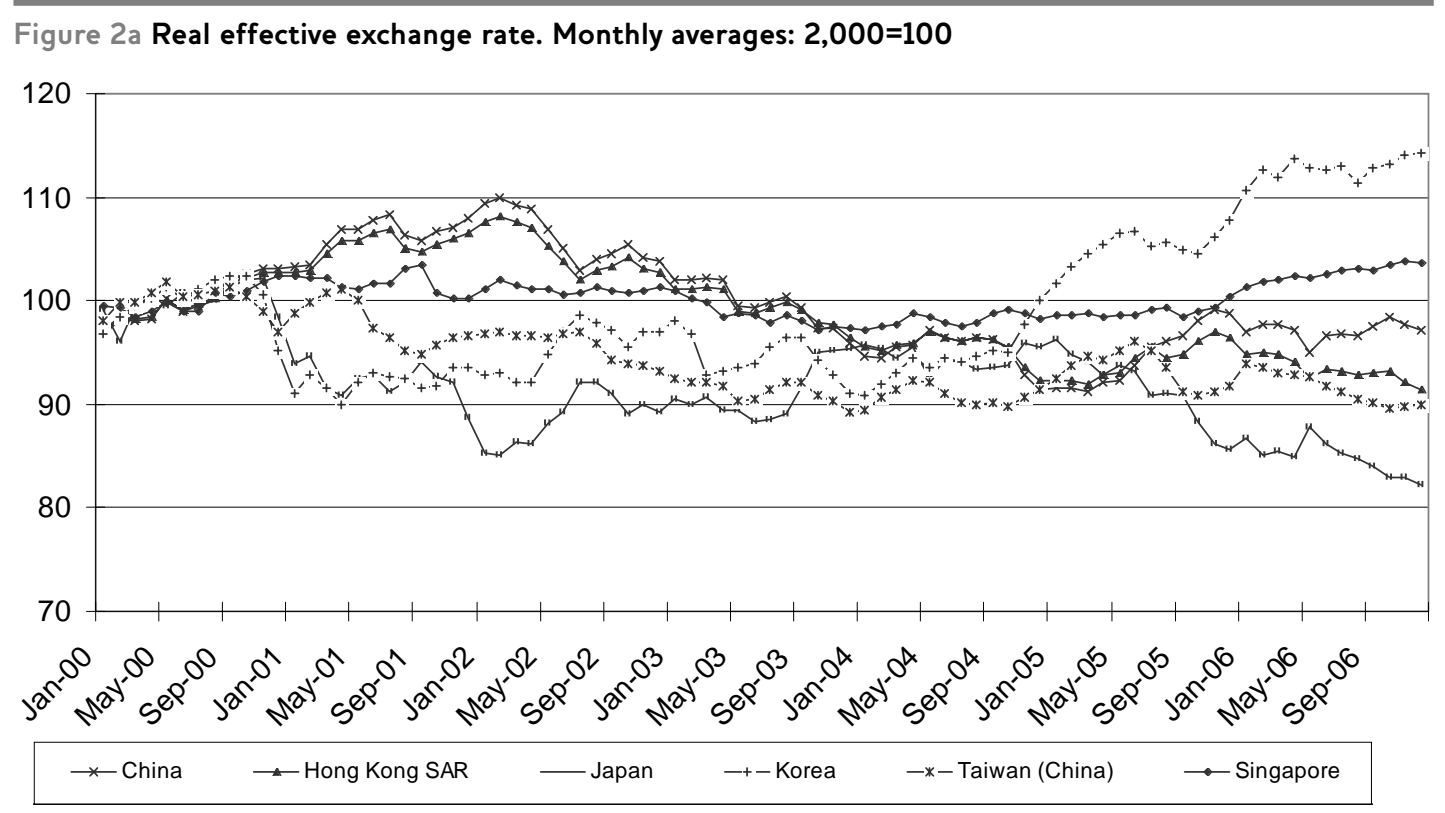

Figure $2 b$ Real effective exchange rate: ASEAN 4. Monthly averages: 2,000=100

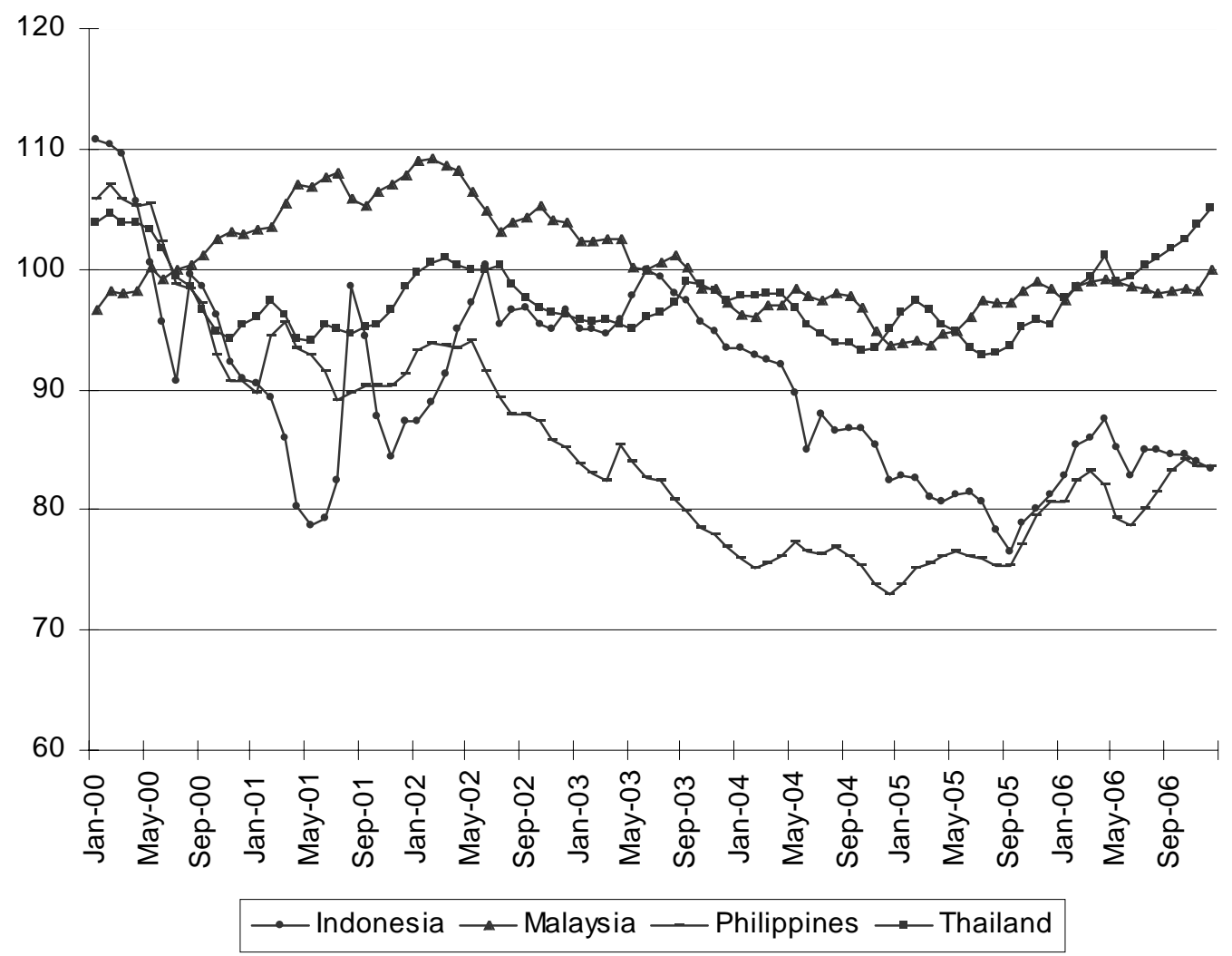

Park and Wyplosz Emerging Economies in East Asia: Are they Safe from Future Crises? 
Table 2 Current account and capital inflows: emerging Asia (billions of US\$)

\begin{tabular}{|c|c|c|c|c|c|c|c|c|c|c|}
\hline & 1996 & 1997 & 1998 & 1999 & 2000 & 2001 & 2002 & 2003 & 2004 & 2005 \\
\hline Current account & -28 & 29 & 119 & 113 & 88 & 91 & 128 & 168 & 187 & 255 \\
\hline Gross capital inflows & 193 & 149 & -121 & 100 & 191 & 65 & 81 & 191 & 346 & 345 \\
\hline FDI inflows & 71 & 81 & 86 & 104 & 139 & 98 & 80 & 83 & 129 & 162 \\
\hline Portfolio bond inflows & 28 & 18 & -2 & -4 & -1 & 1 & 5 & 11 & 22 & 16 \\
\hline Portfolio equity inflows & 18 & 7 & 1 & 95 & 76 & 25 & 10 & 68 & 55 & 88 \\
\hline Derivatives, bank borrowing, etc. & 76 & 43 & -205 & -96 & -24 & -59 & -14 & 29 & 140 & 79 \\
\hline \multicolumn{10}{|l|}{ Gross capital outflows } & -335 \\
\hline Reserves accumulation (-) & -58 & -15 & -57 & -87 & -62 & -86 & -150 & -227 & -337 & -265 \\
\hline $\begin{array}{l}\text { Jote Aggregate data of ten Asian } \\
\text { hilippines, Singapore, Taiwan prov } \\
\text { ource IMF (2006d). }\end{array}$ & 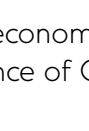 & ( & 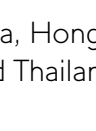 & $d$ & & & & & & \\
\hline
\end{tabular}

demand - business fixed investment in particular has been weak and its growth erratic. As the IMF (2006c) puts it, there is continuing real investment slump in East Asia. The ratio of investment to GDP, which had been in the range of 30-45 per cent in the crisis-affected countries before the crisis, plunged to below 25 per cent on average, even though the saving ratio has remained stable (Figure 1). This divergence explains why current account surpluses have remained positive and large ever since the crisis, when they suung from large deficits to equally large surpluses.

In 2003 and 2004, capital inflows into the region increased sharply. Together with the current account surpluses, this contributed to a surge in foreign exchange reserves throughout East Asia, since most countries allow for limited nominal exchange rate flexibility. In fact, because of the implicit tie to the declining US dollar, real effective exchange rates have depreciated, with the notable exceptions of Korea and Thailand (Figure 2). ${ }^{1}$

One important question is whether the export-led growth process can be sustained. Since the crisis, the share of exports in GDP has risen in all East Asian EMs indicating growing dependence on external demand for growth. Even for such a large economy as China, the ratio is close to 40 per cent. It has more than doubled in Thailand between 1997 and 2005, and increased very substantially in the other countries, especially in Malaysia and Taiwan, during the same period.
Before the crisis, export growth led to an attendant increase in domestic consumption and strong incentives for investment in the exportoriented sector. This causal relation has broken down since the crisis. When the domestic demand is weak as it has been in East Asia's EMs, export promotion itself does not help sustain a high rate of growth and employment unless it produces a surplus on the current account. This feature explains the policy of keeping the currency undervalued. As discussed below in Section 4, this heavy reliance on exports will render most EMs highly vulnerable to the adjustments in global imbalances that will take place eventually. In the event of a substantial weakening of the US dollar vis-à-vis East Asian currencies, compressed US imports from the region would heighten the risk of a deep recession.

So far, a continuing pressure towards exchange rate appreciation has been met by foreign exchange reserve accumulation. This can be costly. Although it has not been so in countries like China (but see Yu Yong Ding in this IDS Bulletin), the capacity of further sterilisation has been very much exhausted in several other countries. It is also raising tension with partner countries outside the region. On the other hand, a sharp appreciation could take the steam out of the growth engine, with possibly wide-ranging consequences. The response of most of the EMs has been to deregulate capital outflows. Although capital inflows in 2005 were as large as those of 2004, they were balanced out by equally large capital outflows 
Table 3 Financial assets (\% of GDP)

\begin{tabular}{lrrrrrrrrr}
\hline & $\mathbf{1 9 9 7}$ & $\mathbf{1 9 9 8}$ & $\mathbf{1 9 9 9}$ & $\mathbf{2 0 0 0}$ & $\mathbf{2 0 0 1}$ & $\mathbf{2 0 0 2}$ & $\mathbf{2 0 0 3}$ & $\mathbf{2 0 0 4}$ & $\mathbf{2 0 0 5}$ \\
\hline China & 148.50 & 168.71 & 186.14 & 204.02 & 234.24 & 255.54 & 267.68 & 224.4 & $\mathbf{2 0 5 . 3}$ \\
Japan & n.a. & n.a. & n.a. & n.a. & 519.30 & 611.70 & 454.20 & 476.3 & $\mathbf{4 5 0 . 5}$ \\
Korea & 127.20 & 171.07 & 216.94 & 195.91 & 213.98 & 217.09 & 242.63 & 270.5 & 260.9 \\
Indonesia & 72.80 & 75.05 & 115.71 & 70.42 & 64.17 & 63.37 & 67.55 & 66.1 & 98.3 \\
Malaysia & 250.50 & 274.10 & 412.39 & 352.49 & 381.36 & 368.91 & 409.16 & 412.4 & 385.4 \\
Philippines & 158.40 & 155.72 & 160.43 & 138.60 & 126.35 & 123.80 & 132.98 & 127.9 & 140.3 \\
Singapore & 259.00 & 327.77 & 468.24 & 373.54 & 375.41 & 349.94 & 441.56 & 452.2 & 474.0 \\
Thailand & 101.90 & 204.38 & 216.88 & 172.70 & 190.39 & 206.31 & 258.95 & 241.3 & 214.5
\end{tabular}

Note Financial assets = sum of domestic bonds, equity market capitalisation, bank assets. Source Ismail (2005), Ghosh (2006) for 2005 estimates; IMF (2006b) for Japan.

(Table 2). At this stage, therefore, the increase in inflows is not likely to cause difficulty in managing either the exchange rate or foreign exchange reserve.

Given the large cushion of reserves, many analysts believe that most East Asian countries can cope with large capital outflows (but, see cautionary comments in Yu Yong Ding, this IDS Bulletin). In fact, it appears that they are now prepared to deregulate capital outflows further, so as to prevent any strengthening of their currencies. This leaves the export-led growth strategy as one of the major macroeconomic structural weaknesses of the region.

\section{Growth, structural changes and stability of the financial sector}

3.1 Growth, liberalisation and structural changes Between 1997 and 2005, except in the Philippines, the size of the financial sector measured by total financial assets as a proportion of the GDP on average more than doubled in most countries (Table 3). The growth of the banking sector has been impressive, but it has been outstripped by the phenomenal expansion of assets in both equity and bond markets (Table 4).

The size of the equity market in Indonesia has more than doubled. The increase has been more than

Table 4 Structure of financial systems (\% of GDP)

\begin{tabular}{lrrrrrrrrr}
\hline Economy & \multicolumn{3}{c}{ Bank asset } & \multicolumn{4}{c}{ Equity market capitalisation } & \multicolumn{3}{c}{ Bonds outstanding } \\
& $\mathbf{1 9 9 7}$ & $\mathbf{2 0 0 4}$ & $\mathbf{2 0 0 5}$ & $\mathbf{1 9 9 7}$ & $\mathbf{2 0 0 4}$ & $\mathbf{2 0 0 5}$ & $\mathbf{1 9 9 7}$ & $\mathbf{2 0 0 4}$ & $\mathbf{2 0 0 5}$ \\
\hline China & 124.6 & 176.4 & $\mathbf{1 6 3 . 1}$ & 11.2 & 23.1 & $\mathbf{1 7 . 8}$ & 12.9 & 24.9 & $\mathbf{2 4 . 2}$ \\
South Korea & 37.9 & 130.1 & $\mathbf{9 3 . 5}$ & 8.1 & 57.1 & $\mathbf{9 1 . 2}$ & 25.2 & 83.3 & $\mathbf{7 6 . 2}$ \\
Malyasia & 100.9 & 169.09 & $\mathbf{1 5 9 . 4}$ & 93.2 & 153.3 & $\mathbf{1 3 8 . 0}$ & 57.0 & 90.0 & $\mathbf{8 8 . 0}$ \\
Indonesia & 31.1 & 14.6 & $\mathbf{4 9 . 8}$ & 12.2 & 28.9 & $\mathbf{2 8 . 9}$ & 1.9 & 22.6 & $\mathbf{1 9 . 6}$ \\
Philippines & 56.1 & 66.5 & $\mathbf{6 3 . 2}$ & 37.7 & 33.0 & $\mathbf{4 0 . 4}$ & 22.4 & 28.4 & $\mathbf{3 6 . 7}$ \\
Thailand & 79.7 & 129.2 & $\mathbf{1 0 3 . 6}$ & 15.1 & 71.4 & $\mathbf{7 0 . 1}$ & 7.1 & 40.7 & $\mathbf{4 0 . 8}$ \\
Singapore & 122.0 & 176.8 & $\mathbf{1 8 5 . 4}$ & 110.8 & 202.3 & $\mathbf{2 2 0 . 4}$ & 24.7 & 73.1 & $\mathbf{6 8 . 2}$ \\
\multicolumn{2}{l}{ Source Ghosh (2006). IMF (2006b). } & & & & & & & &
\end{tabular}


Table 5 Bank non-performing loans to total loans (\%)

\begin{tabular}{|c|c|c|c|c|c|c|c|c|c|}
\hline & 1998 & 1999 & 2000 & 2001 & 2002 & 2003 & 2004 & 2005 & 2006 \\
\hline Japan & 5.4 & 5.8 & 6.1 & 8.4 & 7.2 & 5.2 & 2.9 & 1.8 & n.a. \\
\hline China & n.a. & n.a. & n.a. & 29.8 & 25.6 & 20.1 & 15.6 & 10.5 & 9.8 \\
\hline Hong Kong & 5.3 & 7.2 & 6.1 & 6.5 & 5.0 & 3.9 & 2.3 & 1.5 & 1.3 \\
\hline Korea & 7.4 & 8.3 & 6.6 & 3.4 & 2.4 & 2.6 & 1.9 & 1.2 & 1.2 \\
\hline Singapore & n.a. & 5.3 & 3.4 & 8.0 & 7.7 & 6.7 & 5.0 & 3.8 & 3.8 \\
\hline Indonesia & 48.6 & 32.9 & 18.8 & 31.9 & 24.0 & 19.4 & 14.2 & 15.6 & n.a. \\
\hline Philippines & 12.4 & 14.6 & 16.6 & 27.7 & 26.5 & 26.1 & 24.7 & 20.0 & n.a. \\
\hline Malaysia & 18.6 & 16.6 & 15.4 & 17.8 & 15.8 & 13.9 & 11.8 & 9.9 & 9.5 \\
\hline Thailand & 42.9 & 38.6 & 17.7 & 11.5 & 16.5 & 13.5 & 11.8 & 11.1 & 8.9 \\
\hline \multicolumn{10}{|c|}{ Source IMF (2006b). } \\
\hline
\end{tabular}

tenfold in Korea and almost fivefold in Thailand. Only the Philippines has seen a modest expansion of its equity market. The growth of assets in the bond market, albeit starting from a low base, has been faster than that of the equity market in all East Asian economies. Nevertheless, except for China, the size of the bond market is still much smaller than that of the equity market. ${ }^{2}$ Except for China and Indonesia, by 2005, the size of the combined assets of both equity and bond markets became larger than that of the banking sector. East Asia's financial system no longer appears to be dominated by the banking sector.

Although they are now much more marketoriented, the financial systems are not yet fully liberalised. Liberalisation has been characterised by the lack of agreement on the scope and speed of reform among domestic constituents and marked by relapses and backslidings in many countries in the region. Capital account liberalisation, arguably the last stage of financial reform, has moved at a snail's pace. Chinn and Ito (2006) show that most of the East Asian emerging economies have made little progress in financial market opening in recent years. ${ }^{3}$

Aside from the domestic politics, the official conventional wisdom on financial opening has shifted in response to ambiguous evidence about its effects on growth and financial stability. As Kose et al. (2006) note, emerging economies need to cross several thresholds before they open up their financial markets: deeper domestic financial markets, better- run companies and a disciplined macroeconomic policy. On these criteria, few of East Asia's emerging economies are ready to fully open their financial markets. In addition, the huge build-up of foreign exchange reserves has given East Asia's policymakers a sense of protection and may make them complacent about addressing their financial fragilities.

\subsection{Financial stability}

The Asian financial markets have been widely blamed for the crisis: they had built up large, short positions in foreign currencies; they had lent without adequate caution and they had disregarded standard prudential norms, it was said. In many respects, they have been thoroughly reformed since the crisis, but in some countries, reforms are far from complete. In addition, further regional financial integration may well become an added conduit for crisis contagion.

Official data indicates that the percentage of nonperforming loans has declined substantially since the crisis (Table 5) and that various prudential ratios are above BIS norms, even though they vary a great deal from country to country, with the exception of the Philippines, where there has been a recent decline.

Goldstein and Turner (2004) report that currency mismatch among financial institutions - the villain of the crisis - has declined throughout Asia, with the exception of the Philippines. They also note that 'increases in reserves not only serve to reduce [currency mismatch], but also offer an opportunity 


\begin{tabular}{lcccccccc}
\hline \multicolumn{7}{l}{ Table 6 Financial institutions' transparency $(\mathbf{2 0 0 0 - 6 )}$} \\
\hline Country & $\mathbf{1 9 9 9}$ & $\mathbf{2 0 0 0}$ & $\mathbf{2 0 0 1}$ & $\mathbf{2 0 0 2}$ & $\mathbf{2 0 0 3}$ & $\mathbf{2 0 0 4}$ & $\mathbf{2 0 0 5}$ & $\mathbf{2 0 0 6}$ \\
\hline Japan & 3.32 & 4.52 & 4.22 & 3.44 & 3.85 & 4.44 & 4.63 & 5.38 \\
China & 4.99 & 4.60 & 3.36 & 3.60 & 4.18 & 3.98 & 3.22 & 4.78 \\
Hong Kong & 7.09 & 6.92 & 7.24 & 7.57 & 7.39 & 7.41 & 7.39 & 7.78 \\
Taiwan & 5.67 & 6.03 & 5.90 & 5.58 & 5.67 & 5.75 & 6.07 & 5.38 \\
Korea & 3.39 & 4.29 & 4.59 & 5.05 & 4.37 & 5.21 & 6.00 & 5.14 \\
Singapore & 7.16 & 7.67 & 7.10 & 7.53 & 7.46 & 7.67 & 7.24 & 7.15 \\
Malaysia & 5.88 & 6.29 & 3.65 & 5.89 & 6.35 & 6.94 & 5.85 & 6.72 \\
Indonesia & 3.37 & 4.54 & 4.53 & 3.48 & 3.61 & 4.54 & 4.39 & 4.95 \\
Philippines & 5.82 & 5.83 & 5.21 & 4.73 & 4.61 & 4.56 & 5.19 & 5.63 \\
Thailand & 3.93 & 5.04 & 4.55 & 5.52 & 5.69 & 5.93 & 6.10 & 6.48
\end{tabular}

Note measured on the basis of information provided by financial institutions about their activities. Source IMD (2006).

to deepen domestic debt market' (Goldstein and Turner 2004: 117). ${ }^{4}$

The opaqueness of corporate governance and looseness and unreliability of financial disclosure at East Asian banks were the other factors claimed to have triggered and deepened the Asian crisis. The crisis-hit countries have since then sought to introduce and enforce international standards on the legal and regulatory requirements on information disclosure, shareholder and creditor rights and accounting and auditing standards. Despite these reform efforts, although the available evidence is rather sketchy, it appears that they have not made much progress in governance reform. The World Competitive Yearbook shows that there has been little improvement in the transparency of financial institutions. In fact it deteriorated in China, Taiwan and the Philippines, whereas other countries managed a modicum of improvement between 1999 and 2005 (Table 6). The combination of inadequate disclosure rules - more widely limited transparency of the corporate sector and of large foreign holdings of equities suggests that the equity markets could be quite sensitive to internal and external shocks, possibly the epicentre where financial market turbulences emanate.

In most countries, as the result of consolidation, the average size of banks has increased and foreign ownership has taken hold. Controls over asset and liability management of the banking sector have been removed so that banks are now freer to conduct business in securities and insurance. This should enhance efficiency. Noting that evidence to that effect is lacking, Ghosh (2006) suggests it might be too early to reap the gains from consolidation. At this stage, the main result of the consolidation is a domination of banking by a small number of large banks, which may have undermined competition. As for the efficiency of equity markets in the region, the markets of Hong Kong and Singapore fare relatively well but not those of China, Indonesia, the Philippines and Thailand, which belong to the bottom quartile of efficiency ranking.

Ghosh (2006) finds that the scope of disclosure by the top five banks in East Asia's EMs is relatively broad. Among the crisis-affected countries, Korea and Malaysia, followed by Thailand, have made the most progress in reforming their laws and regulations and practices but these and other EMs in the region have a long distance to travel in protecting minority shareholder rights, in improving the quality of financial reporting and disclosure and in enforcing the rules and regulations. China has only recently begun to strengthen its corporate governance.

The IMF's Global Financial Stability Report (2006a) notes weaknesses in some countries' regulatory 
capacity and legal infrastructure. Since the crisis, revamping and consolidating the system of prudential control of financial markets and institutions has been one of the focal points of the reform agenda throughout East Asia. Unfortunately there are few studies that can shed light on qualitative improvement of the regulatory control system. ${ }^{5}$ According to Kaufmann et al. (2006), the quality of the overall regulatory control has deteriorated in China, Indonesia and the Philippines, and remained roughly at the same level in Malaysia, Singapore and Thailand between 1998 and 2005. Only Korea registered a substantial improvement during the same period.

Several studies show that the two regional cooperative initiatives embodied in the CMl and ABMI together with financial market opening have increased the linkages among East Asia's financial markets over the past seven years. ${ }^{6}$ They also present empirical evidence that East Asia's bond and equity markets have become more closely integrated with those markets of advanced economies in Europe and North America than those of East Asia.

This development is corroborated by an increase in correlations of equity returns across countries in East Asia, though the correlations among bond returns are much smaller (Ghosh 2006). Park and Song (2001) show that during the Asian crisis, Korea would have had a better chance of fending off the crisis had the Thai crisis been contained within its borders. By the time of the hit, Korea's financial markets had not established extensive linkages with the markets of other East Asian economies. The increasingly closer financial linkages between countries therefore mean that financial market disruptions in one country could easily spill over into neighbouring economies, including those with a strong and sound financial system with a higher speed and intensity than before.

\section{Potential vulnerabilities in East Asia}

The first line of defence against financial crisis is built around a macroeconomic policy regime in which financial prices including the exchange rate are flexible enough to deflect or absorb adverse external shocks. In so far as they are fixated on export promotion, policymakers of East Asia's EMs may not be able to hold the first line of defence. Building a resilient financial system that can withstand financial distress constitutes the second line of defence. The preceding review of recent assessments of financial stability does not provide a clear picture as to whether the crisis-affected countries have succeeded in fortifying this line of defence.

The third and final line of defence is to accumulate foreign exchange reserves enough to deter any attack on their currency and to prepare for sudden and massive capital outflows. Given the cracks in the first and second lines of defence, it is not surprising that East Asia's EMs have been driven to buttressing the last line of defence.

The review of stability of the financial system in East Asia points to three potential sources of vulnerability in East Asia. One such source is a crisis either in Indonesia or the Philippines that can be contagious. The two other sources are real asset inflation that may set off a boom-bust cycle and a large depreciation of the US dollar that may precipitate a severe recession. They can reinforce each other to unleash a wave of financial market turbulences throughout East Asia. The epicentres of these financial woes are likely to be located in China and more advanced countries in the region.

\subsection{The Indonesian and the Philippines factor} Fitch Rating (2005) has developed two banking stability indicators. The banking system indicator (BSI) is a measure of intrinsic bank systemic risk on a scale from $A$ (very high quality) to $E$ (very low quality) based on an explicit assessment of the strength of banks standing alone. Another measure is the macroprudential indicator (MPI) with a rating from one to three. The MPI focuses on the coincidence of the trend levels of private sector credit, bubbles in real asset prices, and major currency appreciation, which gives early warning of a common type of banking system stress.

The two indicators suggest that banks in the countries analysed in this IDS Bulletin may not be out of the danger zone. In terms of the BSI, Korea and Malaysia receive a $\mathrm{C}$, Indonesia, Japan, the Philippines, Taiwan and Thailand $\mathrm{a}$ D, and China and Vietnam an $\mathrm{E}$ rating. As far as the macro-prudential indicators are concerned, they do much better with the MPI 1 rating.

The discussion in the preceding sections also suggests that Indonesia and the Philippines are most vulnerable to both internal and external shocks. On the macroeconomic front, the two economies suffer from the highest rates of inflation in East Asia. The 
Table 7 a House price changes (\% change on year

ago)

\begin{tabular}{llll}
\hline & End-2003 & End-2004 & End-2005 \\
\hline Korea & 5.7 & -2.1 & 7.5 \\
Malaysia & 4.0 & 4.8 & 2.4 \\
Thailand & 17.8 & 9.3 & 7.2 \\
Source IMF (2006). & &
\end{tabular}

\begin{tabular}{llllll}
\hline \multicolumn{6}{l}{ Table 7b House price indices (\% change on year ago) } \\
\hline & Q4 2003 & Q4 2004 & Q3 2005 & Q3 2006 & Latest (as of Dec. 2006) \\
\hline Hong Kong & 23.4 & 28.7 & 14.1 & 20.3 & -2.1 \\
China & 5.1 & 10.8 & 6.6 & 5.5 & 5.4 \\
Singapore & -2.0 & 0.9 & 3.3 & 3.3 & 7.6 \\
Japan & -5.7 & -6.0 & -4.7 & -5.4 & -2.7
\end{tabular}

Source The Economist, 7 December 2006, 8 December 2005 and 3 March 2005.

size of their government debt may not be sustainable. Although they have been generating a current account surplus, it is shrinking. After three years of sustained depreciation that improved the competitive edge of their exports, their real effective exchange rates have been appreciating since the third-quarter of 2005. Short-term foreign debt as a percentage of foreign reserves rose to more that 100 per cent in Indonesia in 2006, making it a likely target of a speculative attack. The ratio has been lower in the Philippines, but at almost 40 per cent, it may be too high to keep speculators at bay.

Changes in many of the financial stability and governance indicators also cast doubt as to the soundness and resilience of their financial systems. In the Philippines, non-performing loans have been on average more that 25 per cent of total loans of banks, which is the highest in the region, since 2001. Indonesia has been successful in removing bad loans at banks, but the non-performing loan ratio at more than 15 per cent is still too high to be out of the danger zone of crisis. To make matters worse, Indonesia's provisions for bad loans are hardly adequate and so is its bank regulatory capital to assets.

Very worrisome is that banks in the Philippines are exposed to a high degree of currency mismatch in their balance sheet, in fact twice as high as the degree of Korea at the time of the crisis in 1997.

If a crisis erupted in either country, would it be contagious? The majority view is that contagion will not be as pervasive as it was during the 1997-8 crisis. It is said that regional as well global investors have now access to better information about local economics and politics and that they have become much more sophisticated in assessing risks. It is therefore argued that they have become selective and discriminating in investing in East Asia as shown by the divergent movements in the spreads (JP Morgan EMBI + Index). All of this suggests a lower probability for a crisis in one country to create panic among or trigger herding of investors to cause massive capital outflows in other healthier economies. However, past experience shows that crisis behaviour is essentially unpredictable.

\subsection{Asset inflation and real estate market bubble}

Having experienced the boom-bust real estate market cycle in the run-up to the 1997 crisis, East Asian countries cannot take lightly rising asset and housing prices. Some countries - China, Korea, Malaysia and Thailand - all have seen substantial increases in housing prices over the last few years (Table 7). In China and Korea, there are bubbles in the 


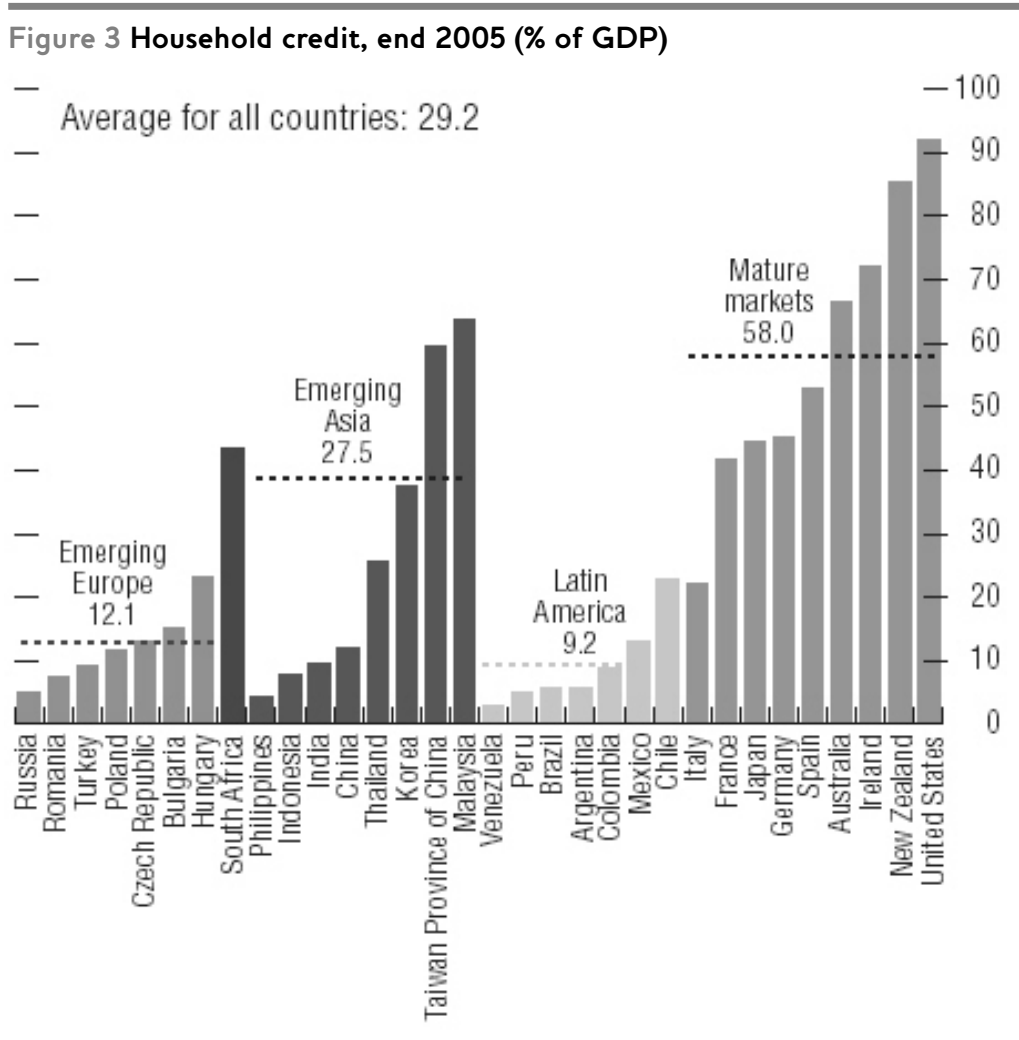

Source IMF (2006c).

making in real estate markets. It is difficult to judge whether this evolution could trigger a crisis as it did before. Looking at the likely causes may help clarify the situation.

Relatively easy monetary policy and abundant global liquidity have driven interest rates down to historic lows, boosting the demand for housing and other types of real estate. As is often the case, as the prices of real estate started rising, it has generated an expectation that they will continue to rise, thereby fuelling a boom.

As shown in the preceding section, bank assets and equities as a percentage of the GDP recorded almost a threefold increase in Korea between 1997 and 2005. They more than doubled in Thailand, and jumped up by 109 percentage points in Malaysia during the same period. China has recorded a more modest increase of about 77 percentage points. The markets for bank assets and equities in these economies tend to be very liquid, and there is the danger that any change in price expectations of real estate could unleash a massive shift of funds to and from the real estate markets, thereby amplifying the boom-bust cycle.

The major shift in bank lending to households from businesses is also playing a role in house price inflation. The slump in investment throughout the region has curtailed the business demand for bank loans. Unable to find creditworthy corporate borrowers, banks and other non-bank financial intermediaries have aggressively sought to increase their loans to households, the bulk of which have been mortgage loans. As shown by the recent data compiled by the IMF (2006c) and the World Bank (2006), household credit has grown across eight emerging economies in East Asia. ${ }^{7}$ It was on average close to 28 per cent of GDP at the end of 2005 as compared with 12 and 9 per cent in emerging Europe and Latin America, respectively (Figure 3). The ratio is certainly less than half of the level of advanced economies, but the rapidity with which it has grown in East Asia is quite dramatic. The average growth rate of 22.6 per cent of real household credit for the eight countries was more than twice 
Figure 4 Annual growth of real household credit (\% of GDP)

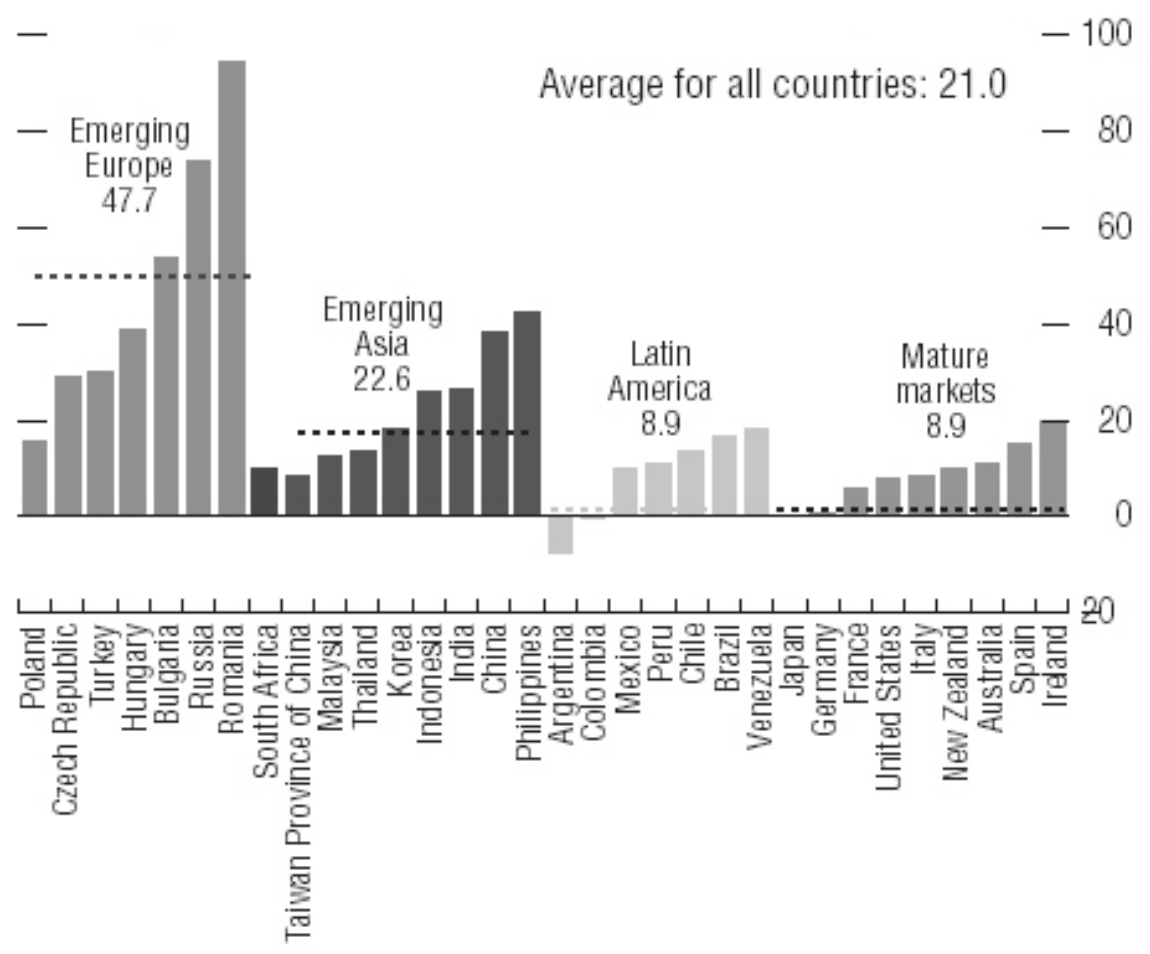

Figure 5 FED tightening and EM spreads

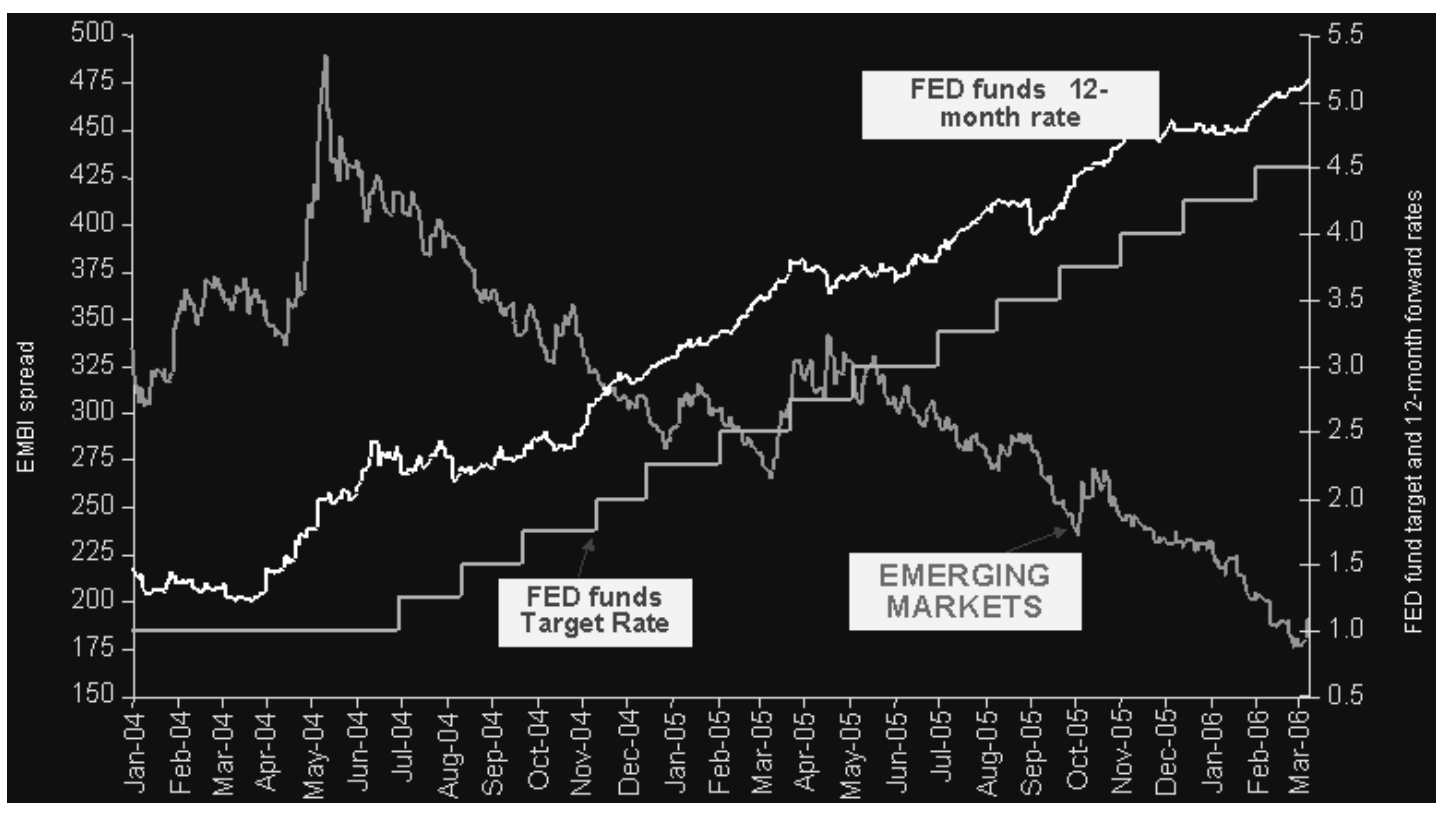

Source Blejer (2007).

Park and Wyplosz Emerging Economies in East Asia: Are they Safe from Future Crises? 


\section{Figure 6 Risk premia for emerging markets}

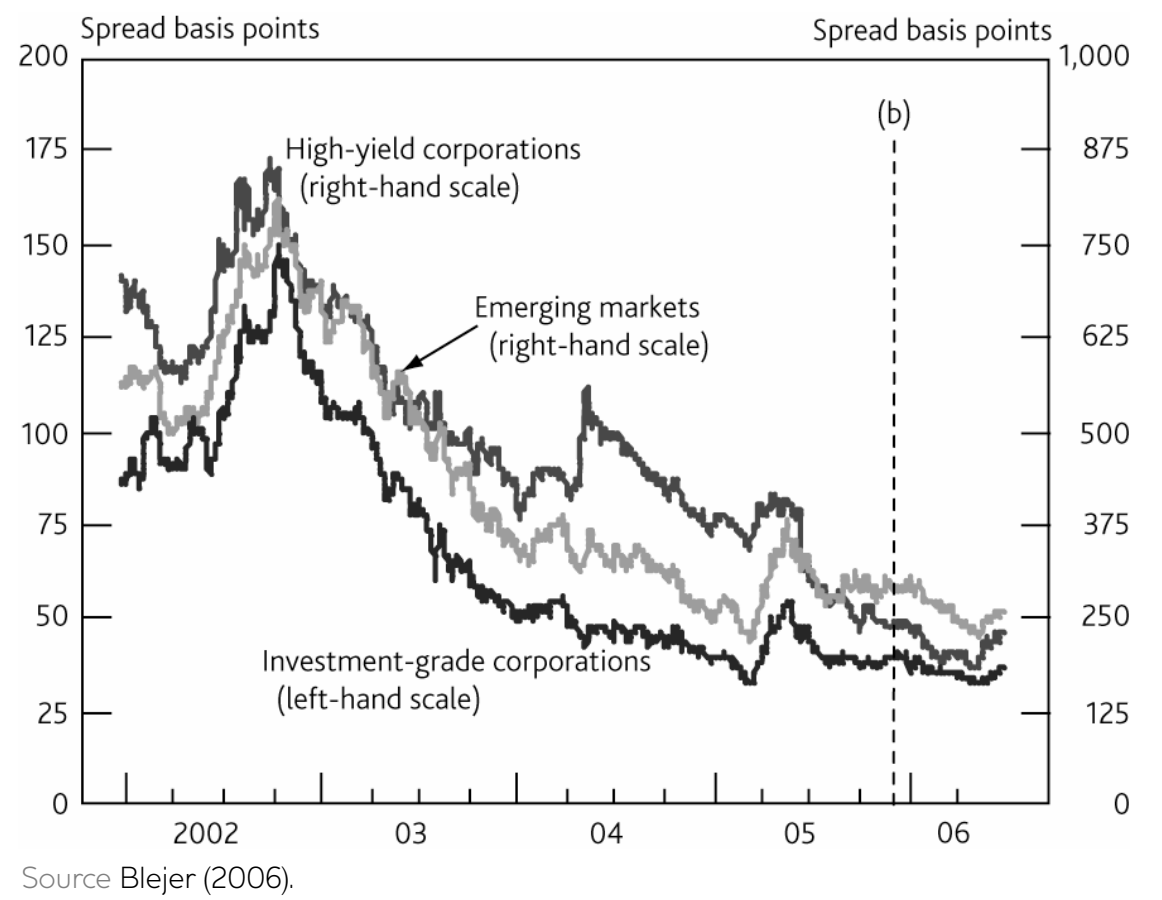

the rates of mature economies and Latin America during the 2000-5 period (Figure 4). The bulk of household loans was extended for housing finance to raise the share of housing loans in total household credit to more than 54.2 per cent compared with around 35 per cent ${ }^{8}$ in 2000.

Measured in market values, housing markets are large compared with other asset markets. For example, the total value of apartment units alone was more than twice the size of nominal GDP at the end of 2005 in Korea. The housing market tends to be volatile because on the demand side, housing has become more like a tradable asset due to low transaction costs and high market liquidity, while the supply is rather unresponsive to its price changes in the short run.

What would happen if the boom comes to an end? If the current trend continues, the familiar scenario of the boom-bust cycle could well unfold. Rising asset prices encourage further credit growth by raising collateral values, so that an eventual decline in inflated property prices may result in a slowdown of the economy. When the interest rates rise or growth decelerates, household balance sheets come under pressure and a sudden stop in the housing market boom piles up non-performing loans at banks and other financial institutions. The risk is enhanced in the absence of adequate risk management and prudential regulatory infrastructure.

The end of the boom can then be followed by a decline in consumption and construction investment, as happened during the Asian crisis. How damaging could the collapse of the housing market be? As discussed below, a large depreciation of the dollar, if it occurs, is likely to cause a large currency appreciation and a severe recession throughout East Asia. The recession could well end the housing boom and also bring about a collapse of the equity market. ${ }^{9}$ Support for this view is provided by the co-movement between equity and housing prices in Hong Kong, Korea and Singapore, which suggests that the wealth effect dominates the substitution effect associated with price changes of the two assets (see Shu 2006).

The end of the boom itself is unlikely to be as damaging as it was during the 1997- 8 crisis but the ensuing decline in equity and real estate prices could cause large capital outflows, possibly even touching off a major crisis, as it did before. An optimistic view 
is that, given that short-term foreign loans account for a much lower share of total foreign debt, the outflows might not deplete the ample reserves, especially if the authorities are prepared to let the exchange rate depreciate in response to the outflows. We return to these two assumptions below.

\subsection{Export-led development strategy and the collapse of the dollar ${ }^{10}$}

The current account deficit of the USA surpassed 6 per cent of GDP in 2006. There is a widespread consensus that such a large deficit, which is the major source of imbalance between the USA and East Asia, cannot be sustained. Despite the potential convergence of interest, the key players on both sides of the Pacific China, Japan and the USA - have not taken any coordinated policy responses that would signal their intention to resolve the imbalance. This inaction may lead markets to conclude that the main players are unable to agree on the direction of needed policy changes and hence increase the risk of a market-led adjustment that will involve abrupt and excessive changes in major exchange rates and asset prices, triggering a global recession and aggravation in trade frictions. Recent studies suggest that the effective exchange rate depreciation of the dollar required to reduce the US current account deficit to 3 per cent of the GDP in the medium term ranges from 15 to 20 per cent (see Baily 2007). A sharp depreciation of the dollar, accompanied by a sudden compression of the US current account deficit, could then provoke a deep recession in East Asia, as the region heavily depends on exports for growth, the bulk of which is destined for the US market. Whether this slowdown could sow the seeds of another financial crisis is not clear.

The previous episodes of financial crisis imply that the dollar depreciation would raise US interest rates and lower US Treasury prices, which could in turn precipitate a flight to quality by investors in advanced countries that leads to sudden stops in capital inflows and heightens volatility in emerging financial markets. "1 The curtailment of capital flows toward the USA would then lead to higher US Treasury benchmarks and wider emerging-market bond spreads, especially for borrowers with high ratios of debt to GDP. This time around, the emphasis on the impact on financial markets of a fall in the dollar is likely to be ambiguous, more so in East Asia.

This ambiguity stems from the observation that the positive correlation between US interest rates and emerging market spreads, a key assumption in this analysis, is less pronounced and less stable than suggested by the scenario. For a number of countries and periods this correlation has been essentially nonexistent (Eichengreen and Mody 1998). As shown in Figures 5 and 6 , emerging market spreads have been declining while the US interest rate has been rising. If the higher US rates are caused by sudden evaporation of the willingness of foreign investors to finance the country's current account deficit and from the inflationary effects of the consequent fall in the dollar, then they will be accompanied by lower interest rates in the rest of the world. With less liquidity flowing to the USA, more liquidity will remain in other markets. ${ }^{12}$ If the dollar falls, foreign interest rates must be lower than US rates by the amount of expected foreign currency appreciation in order to satisfy the no-arbitrage condition. And if higher interest rates in the USA are accompanied by lower rates in Europe, then it is not obvious that emerging markets will be adversely affected.

For emerging markets to feel a strong negative impact, one must add another element that produces a significant drop in global liquidity, for example a sharp adjustment of US asset prices that produces distress, or at least fears of distress, among financial institutions, as happened in the bond market correction of 1994 and the LTCM (Long-Term Capital Management) crisis of 1998. Such fears could result in de-leveraging by foreign as well as US financial institutions, reducing global liquidity. They could produce a global flight to quality and, in particular, less appetite for emerging market debt, as happened in these earlier periods.

But East Asia has greatly reduced its dependence on new foreign borrowing. As a group, the East Asian countries are running current account surpluses; they have no need for additional foreign debt. In fact, they have been reducing net external debt by accumulating reserves. It is true that if the US current account abruptly moves to balance, current accounts in Asia and Latin America will have to move to balance as well, assuming that Europe's current account balance remains where it is, at zero. When debt is maturing it will have to be rolled over or paid back, but the amount of debt to roll over is very small in East Asia: excluding Indonesia, at the end of 2005, short-term foreign debt including those long-term obligations maturing within a year range from 17.6 per cent in Malaysia to 40 per cent in the Philippines of reserves. 


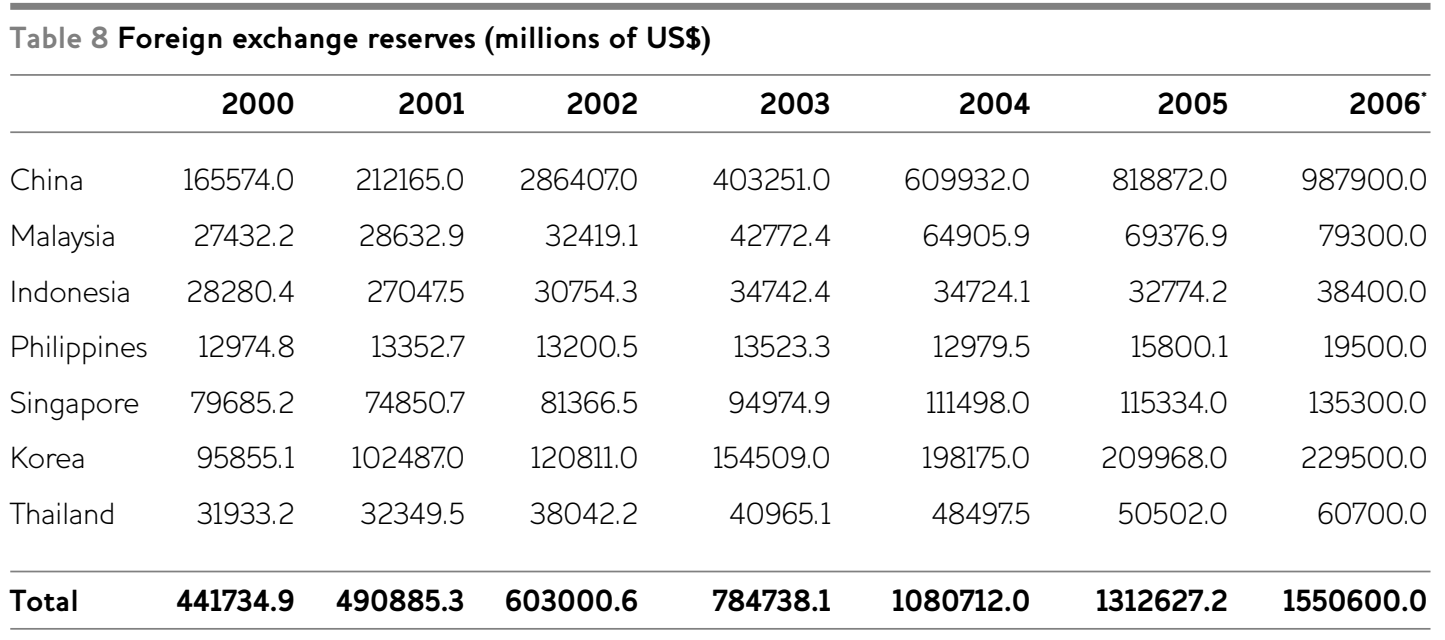

* Excluding gold, except Singapore and China, IMF definition.

Source IMF, The Economist (16-22 December 2006).

This means that in the unlikely event where all funding suddenly becomes unavailable, East Asian countries could still retire their maturing obligations and meet their other external financial needs without depleting their reserves.

While East Asia's countries seem reasonably well insulated from the distress caused by a dollar depreciation transmitted through the financial channel (even though sources of financial distress may arise from unexpected channels), this does not mean that they are immune to a fall in the dollar. On the contrary, they will suffer severely through the trade channel. The elimination of foreign financing for the US current account would force its net imports to decline by some 7 per cent of US GDP. Since it would take time for a dollar depreciation to crowd in additional US exports, it is reasonable to assume that the entire swing comes in the form of falling US imports.

As a first approximation, assume also that the dollar falls by the same amount against all foreign currencies, reducing US imports across the board. The impact on various regions depends on the importance of exports to the USA as a share of regional GDP. In 2005, this share varied. For the larger East Asian economies (Indonesia, Malaysia, the Philippines, South Korea and Thailand) and China, they would be relatively high, up to 15 per cent. ${ }^{13}$ Thus a disorderly correction of the US current account imbalance should have the largest impact on emerging markets most dependent on exports to the USA, which means above all, the small entrepot economies of East Asia (such as Hong Kong or Singapore). Looking at the issue comparatively, East Asia is more vulnerable than Latin America, mainly because the Asian region is more open and closely linked to the USA.

A less sanguine view allows for a significant slowdown in the USA and a more modest slowdown in China induced by the appreciation of the renminbi to differentially impact commodity exporting countries. For example, if demand growth in the USA and China and therefore demand growth globally were to slow, the terms of trade of commodity exporters like Indonesia would be hit. Conversely, developing countries that depend on commodity imports, which means mainly the resource-poor East Asian countries, will experience weaker commodity prices as a partial cushion against slower global growth.

In sum, the principal risk to stability in East Asia from the current pattern of global imbalances lies in the possibility of a disorderly correction that would precipitate a major slowdown in US growth and a significant rise in US interest rates. But in contrast to the experience of the Asian crisis, the risk to East Asia would not lie this time in the financial consequences. These countries are running current account surpluses rather than deficits, minimising their borrowing. ${ }^{14}$ And as pointed out in the previous 
Figure 7 International reserves

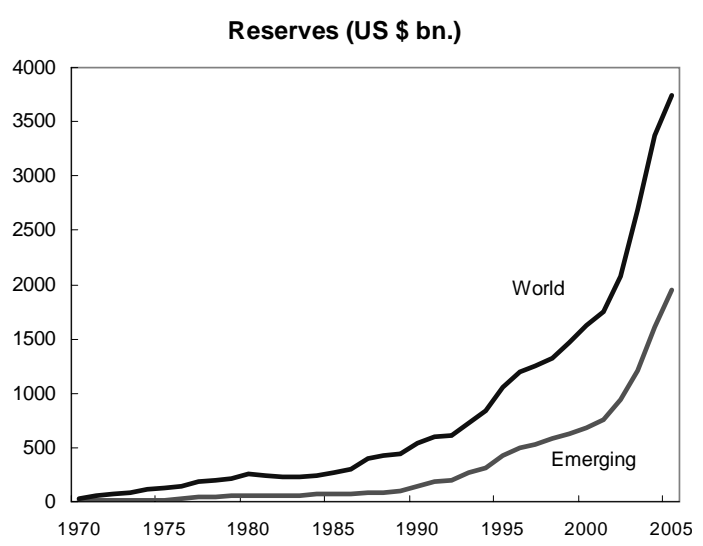

Source IFS (2006) and Lane and Milesi-Ferretti (2006).
Reserves/External liabilities

(unweighted averages)

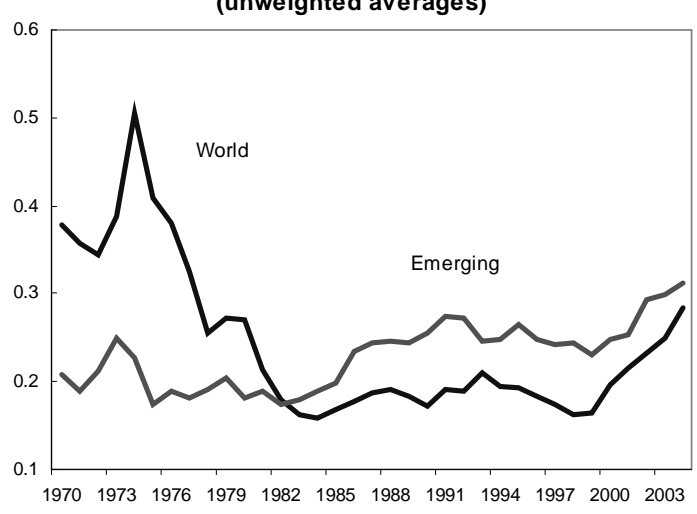

section, there are not many internal imbalances or glaring structural weaknesses, certainly not as many as before. This is not to imply that the exceptionally low level to which emerging market spreads have fallen will be sustained. But ample international reserves could help countries to compensate for a flight to quality and adverse shifts in the price and direction of international capital flows.

At present, the main risk stems from the possibility of a significant slowdown in US growth and, more specifically, in the growth of US net import demand. The incidence of the effect varies with trade openness and more specifically with dependence on exports to the USA. In Asia, exposure to the danger of a disorderly correction is greatest for countries like Singapore, Hong Kong and Taiwan, which are highly open and export heavily to the USA. In addition, the impact will tend to vary with the policy response, not just with the extent to which currencies are allowed to move but with macroeconomic policy generally.

\section{Reserve accumulation as self insurance and precautionary demand}

At the end of 2006, the seven East Asian countries - ASEANS plus China and Korea held a total of more than US\$1.5 trillion in foreign exchange reserves (Table 8). As a proportion of the GDP, reserve holdings ranged from 100 per cent in Singapore to 11 per cent in Indonesia. Short-term foreign debts as a percentage of total reserves have also declined markedly in all countries since 1997. Except for Indonesia, the reserve holdings are often seen as excessive. It is argued that this is a wasteful use of

precious resources, which could be better used in building private and public productive capital. It is further argued that the accumulation of reserves is the other side of the coin of an aggressive exportled development strategy based on the systematic undervaluation of exchange rates.

\subsection{Are international reserves excessive?}

A first issue is whether these reserves are really excessive. This requires agreeing on how to measure them. Discussions about international reserves usually start with a figure like the left chart in Figure 7 , which is spectacular, but whose implications are far from obvious. The usual procedure is to scale the reserves by measures such as GDP, exports or imports. When this is done, the impression that reserves were abruptly built up starting in the late 1990s remains, which has led many observers to conclude that this accumulation has been excessive.

Implicitly, this assessment assumes that reserves should grow with the size of the economy as measured by GDP or with the size of external trade. It is very unclear what lies behind the view that GDP is an appropriate scaling variable. As for trade, the usual justification is that countries need to have enough reserves to meet unexpected disturbances, with sufficient means to avoid a sudden stop in essential imports. Indeed, it used to be that international institutions recommended that reserves represent at least three-months worth of imports. Such a recommendation draws the attention to two features. The first one is the idea that reserves constitute a form of insurance against unexpected 
disruption. The second one is the implicit view that either the trade balance is where balance-ofpayment disturbances mostly occur, or that the main risk to be insured by reserves concerns the financing of recurrent trade deficits.

The prevalence of the trade balance as the main source of unexpected disturbances may be an acceptable assumption for low-income developing countries that are characterised by export specialisation in a narrow range of staple goods, often raw materials. This assumption does not apply to emerging market countries characterised by welldiversified exports. Obviously, emerging market countries are unlikely to face a situation where export earnings may decline abruptly to the point that they can no longer pay for imports, essential or not.

The main source of uncertainty for emerging market countries lies in the capital account, not the trade balances. The Asian crisis is a clear case in point. For these countries, therefore, the proper scale variable is neither GDP nor exports but some measure of exposure to sudden capital outflows. Which measure? One possible measure, directly inspired by the Asian crisis is external debt. For example, the Greenspan-Guidotti-Fischer rule recommends that reserves be at least equal to short-term debt. The chart on the right in Figure 7 shows how different things look when external liabilities - irrespective of maturity - are used to deflate reserves. Although reserves as a ratio to external liabilities have grown in recent years, there is hardly any historical standard to brand them as excessive. However, if reserves were compared with short-term debt, there would be an increase in the ratio, showing an important strengthening of defences.

The contrast between the two charts further shows that countries which become financially integrated face radically changed reserve needs. Some Asian countries have gone far in responding to these needs. For example, China's reserve accumulation has picked up speed recently and the case of Korea is similar.

\subsection{Good and bad reasons for reserve accumulation} As noted before, one good reason for holding reserves is to insure the country against sharp and sudden reversals in the balance of payments. Emerging market countries should focus on their capital account. $A$ second reason is what Aisenman and Lee (2006) call 'mercantilism'. The Asian countries' export-led growth strategy is sometimes seen as a case of mercantilism. Which reason applies and how to evaluate the motives has recently become the object of investigation.

The importance of self-insurance has been documented by Lee (2004) and Aisenman and Lee (2007). They conclude that self insurance in the presence of the risks of systemic sudden stops, defined as periods of skyrocketing aggregate bond spreads and large capital flow reversals is the main reason for reserve accumulation. Using a calibrated theoretical model, Jeanne and Rancière (2006) reach similar conclusions. They provide convincing evidence that the self-insurance motivation explains much of the recent reserve build-up. Yet they note that, according to their model, Asia's accumulation may be excessive.

In fact, many Asian countries do not conceal that they take a rather stringent view of self-insurance. Their intention is to rule out the need to apply to the IMF for emergency loans as they did in 1997-8. Then and now, they consider that the conditionality attached to these loans was ill-designed and violated their sovereignty. The rejection by Malaysia of these conditions, and the controversial evidence by Kaplan and Rodrik (2001) that Malaysia fared at least as well as the other countries, is seen as an example to be followed should a new crisis erupt. Fear of the IMF, therefore, may explain why Asian countries are 'buying' more self-insurance than other countries.

The alternative explanation to self-insurance is mercantilism. The prime suspect in this game is China which, as noted above, stands apart for its rapid reserve build-up. Is there a plausible alternative explanation? One possibility is the state of its banking sector. China may well have larger than usual needs for reserves to face a potential banking crisis. It is not known how large the net foreign currency liabilities of Chinese banks are. If they are large, the authorities may have to promptly intervene in case of stress. If this intervention triggers a currency crisis, the authorities need to have yet more reserves to stabilise the exchange rate.

Whatever the true motives behind reserve accumulation may be, it is clear that many East Asian policymakers are not persuaded that the reforms of their financial, corporate and public sectors, together with a range of institutional reform, are sufficient to rule out future crises. It remains to be seen whether 
the stocks of accumulated reserves are large enough to fend off currency attacks mounted by determined speculators.

\subsection{What is the problem with large reserves?}

The standard argument against large reserve stocks is that they are costly to the country that holds them. Obviously, returns on high-grade liquid assets are low, not just in comparison with other assets but, it is claimed, also with the returns from domestic productive investment. Comparing costs and returns on foreign assets, Rodrik (2006) puts the cost at 1 per cent of GDP when reserves amount to 30 per cent of GDP. Other estimates give different results; sometimes they even find that the costs can be negative.

Most estimates of reserve costs assume that domestic investment provides a higher social return than liquid foreign asset holdings. This assumption, however, is questionable. Holding foreign reserves may represent a very decent use of emerging market country savings. The Lucas paradox - the fact that capital tends to flow from developing to developed countries - has shown that returns from investments in many developing countries may be very low, if not negative. $A$ further reason to question the view that returns from international reserves are comparatively low is related to possible limits to domestic investment. With a savings rate close to 50 per cent of GDP, China faces a serious absorption capacity hurdle. It is reasonable to assume that there exist physical limits as to how much new investment, inclusive of public investment, can be carried out. China probably must invest some of its savings abroad. It could do better than acquiring low-yield bonds but there too, as has been shown recently, the willingness to allow for a build-up of Chinese ownership of private stocks is not unbounded. More generally, coupled with a high saving rate, the investment slump described above suggests that many East Asian countries have no choice but to acquire foreign assets.

As we know from finance principles, comparing returns is not enough to decide the proper share of assets in any portfolio. In addition, holding a large stock of reserves does not mean that the assets must be held in just one form. Indeed, some countries (Korea, for example) actively manage their portfolios.

Leaving aside the asset allocation issue, the potential opportunity cost of assets must be related to potential benefits. If the main purpose is export-led growth, the potential benefits can be very large. Of course, currency undervaluation imposes an additional cost to trading partners, but the cost-benefit balance may be favourable for the country in question if there exist fixed costs, market distortions or increasing returns. There seems to be no study that attempts to measure the existence and extent of such benefits, and further research may be required.

If the main purpose is self-insurance, some cost of holding reserves can be justified again. But what exactly is the risk that is insured and how is it covered? Currency crises can be very expensive, especially when they are accompanied by banking crises, as is often the case. Estimates of these costs range from 10 to 25 per cent of GDP, sometimes even more and these estimates overlook the social and political costs of severe crises (see also the Introduction to this IDS Bulletin). Assuming that reserves of, say, 100 per cent of GDP are apt to provide the sought-after protection, an assertion that is challenged below, the Rodrik estimate implies an annual cost of about 3 per cent of GDP. Further assuming that crises costing 25 per cent of GDP may arise once in a decade, even ignoring discounting, the insured expected risk is of the order of 2.5 per cent of GDP. This would suggest that self-insurance via foreign exchange reserves is not particularly attractive. Of course, we would need to add the non-economic costs of financial crises - social pain and instability, political turmoil, wealth redistribution and moreespecially impact on increased poverty, as well as the possible long-term loss of economic dynamism.

The matter becomes even more complicated once we allow for moral hazard. As discussed above, there are many ways for a country to reduce the odds of a crisis and to make its consequences less dramatic. The experience of the developed countries suggests that both the odds and the consequences can be considerably reduced by adopting adequate structural and macroeconomic policies. Self-insurance becomes excessively expensive if a large stock of reserves acts as a disincentive to adopt these policies, especially since most of them carry additional favourable supply-side benefits.

The second issue concerns the question of what selfinsurance really achieves. Foreign exchange reserves are not really an insurance mechanism: they do not pay back a fraction of the costs, they are only meant 
to reduce the odds of a crisis. The deep question, then, is whether they offer an iron-clad protection. There is no consensus on this question, for lack of empirical investigation. In theory, there is little doubt that large reserves may deter crises, but there is no guarantee that the deterrent is always effective. Even if reserves meet the Greenspan-Guidotti-Fischer rule and are equal to short-term debt that may not be enough once we allow for short positions (via derivatives) and capital flight. Jeanne and Wyplosz (2003) show that determined markets can quickly build up virtually unlimited speculative positions.

The main role of reserves is therefore to prevent reaching a situation where the markets are sufficiently determined to challenge the authorities' willingness to commit their reserves. In doing so, the authorities must be willing to take on serious losses. More importantly, perhaps, they must be able to sterilise massive interventions, which mean seriously re-shaping the balance sheets of domestic commercial banks and corporations. Indeed, consider commercial banks that sell foreign currency forward to domestic and international speculators. The central bank may need to stand ready to provide these institutions with the foreign currency that they will have to deliver and, at the same time, extend domestic currency credit to keep the money supply unchanged. When the banking sector is relatively fragile, large-scale sterilisation may become a hazardous undertaking. Replacing a currency crisis with a domestic financial crisis is not particularly appealing. ${ }^{15}$

In the end, the conclusion is far from clear-cut. On the one hand, the costs of large foreign exchange reserves may be significantly less than is commonly assumed. On the other hand, the self-insurance value of large reserve stockpiles may be exaggerated. While Asian countries may be getting a decent return from their high foreign exchange reserves, they may harbour a mistaken sense of immunity from financial crisis.

\subsection{The regional dimension}

Assuming that reserves are excessive and that the accumulation is partly, at least, explained by the export-led growth strategy, it remains to be seen how East Asian countries can respond. The exportled growth strategy implies a desire to hold down the real appreciation that accompanies economic catch-up. The main reason for giving up the strategy is that it has a strong beggar-thy-neighbour flavour but who are the neighbours?

A first class of neighbours includes the rest of the world. This is where the export-led growth strategy is often strongly criticised. A cooperative approach requires that all Asian currencies be allowed to appreciate in real terms vis-à-vis the currencies of the developed countries. The solution favoured by the developed countries and the IMF is exchange rate flexibility. The assumption behind this option is that market forces will drive each country's real exchange rate to its equilibrium level, and will keep it appreciating as long as catch-up unfolds. If things were that simple, this would be the ideal solution.

This solution may not be as ideal as its proponents expect it to be. In the absence of foreign exchange market interventions, the balance of payments would be balanced and reserves would not be accumulated any more. If financial integration deepens, as gross foreign-currency liabilities expand, the authorities might want to keep reserves growing, which would not be possible anymore. The answer is that when the exchange rate floats, the needs for reserves greatly diminish. This may be so, but central banks still must assume the lender of last resort function, which may require large stocks of reserves if the financial institutions hold large amounts of liquid foreigncurrency liabilities. Furthermore, even if the currency floats freely, current account surpluses could still occur because of the high saving rates that prevail in East Asian countries.

Of course, the idea that floating exchange rates keep the real rate close to its equilibrium level is strongly contradicted by the facts. Floating exchange rates are highly volatile and this volatility is now known to be fairly disruptive to trade flows. For countries that view exports as a growth driver, this is a very unappealing prospect. $A$ particular concern is the second class of neighbours, namely the regional trading partners. Given the depth of regional trade integration, bilateral exchange rates are a major concern. ${ }^{16}$ If random fluctuations vis-à-vis the major currencies translates into random fluctuations of bilateral exchange rates, the reluctance of Asian countries to let their currencies freely float becomes understandable.

This observation suggests yet another interpretation of reserve accumulation. Assuming that all Asian 
countries conclude that it is in their collective interest to stop accumulating reserves and to allow for exchange rate flexibility, they would each stand to benefit from coordinating the policy move. Absent of any agreement, the natural outcome is to wait for the others to move first. Indeed, moving first implies taking the risk of seeing one's exchange rate appreciate vis-à-vis all other currencies, both regionally and beyond. Thus, it is conceivable that the lack of any agreement - despite some progress following $\mathrm{CMI}$ and $\mathrm{ABMI}$ - acts as a stumbling block.

\section{Conclusions}

Since the crisis, most East Asian countries have achieved much progress in making their financial systems less crisis-prone and more crisis-resilient. They have also continued to conduct prudent macroeconomic policies. And they have accumulated impressive stockpiles of foreign exchange reserves. $A$ key motivation behind these momentous efforts is a shared desire to avoid being caught again in a financial crisis. Has this objective been achieved?

We argue that the risks have been considerably reduced but, unsurprisingly perhaps, that they have not been eliminated. Financial systems are a lot safer but there is no such thing as a perfectly safe financial system. Large amounts of foreign exchange reserves may deter some speculative attacks, but they may be overrun by well-determined speculators. In addition, progress has been uneven from country to country. As a result, weak spots survive and regional contagion remains a threat, albeit a distant one. The natural question is what else can and should be done to further reduce the odds of financial crises.

\section{Notes}

1 In the case of Japan, large capital outflows have been the cause of the yen depreciation.

2 Ghosh (2006) shows that in terms of the size of the bond market relative to the per capita income, East Asia lags behind other emerging economies elsewhere, such as Latin America. Furthermore, much of the growth has come from the increase in government bond financing for the acquisition of non-performing loans at insolvent financial institutions as part of the crisis resolution. Partly for this reason, the corporate bond market is much smaller than the government bond market. One of the major constraints on the growth of the bond market has been the limited liquidity in the secondary markets.

3 In contrast, however, Ghosh (2006), using the IMF data, provides a totally different picture that 'Regulation prohibiting or restricting capital inflows and outflows have been progressively reduced, and, except in China, they are now fairly minimal' (2006: 37)

4 Goldstein and Turner (2004) also point out that better macroeconomic and exchange rate policies, developing domestic bond markets, and improving efficiency of financial oversight are critical to limiting the degree of currency mismatch. Not many East Asia's EMs, it seems, have taken these precautionary measures seriously.

5 According to the GSFR, EM policymakers need to develop a comprehensive legal and regulatory

framework and infrastructure for better assessment of systemic risk and their mitigation.

6 See Eichengreen and Park (2006), Kim et al. (2005), Shin and Yang (2006) and Jeon and Yang (2005).

7 They are: Taiwan, Malaysia, Thailand, Korea, Indonesia, India, China and the Philippines.

8 An estimate.

9 Shu (2006) shows that an appreciation of the dollar exchange rates is associated with housing booms and vice versa, in particular in countries that adopt flexible exchange rates.

10 This section draws on Eichengreen and Park (2006).

11 See the World Bank (2006).

12 This is an implication of the interest parity condition.

13 Oil exporters also rely heavily on the USA for their final market, but they are a special case.

14 As noted above, even if the current account is in surplus, the current account minus debt amortisations can still be a negative number, rendering them dependent on capital flows. And a current account surplus only eliminates a country's dependence on capital inflows; it will be less than comforting if a country experiences large capital outflows.

15 Capital controls may reduce the size of the undertaking.

16 The importance of this observation for exchange rate arrangements is examined in greater detail in Park and Wyplosz (2004). 


\section{References}

Aisenman, Joshua and Jaewoo Lee (2007) 'International Reserves: Precautionary vs. Mercantilist Views, Theory, and Evidence', Open Economies Reviews, forthcoming

Asian Development Bank (2006a) Asia Economic Monitor 2006, Manila: ADB

Asian Development Bank (2006b) Key Indicators 2006: Measuring Policy Effectiveness in Health and Education, Manila: ADB

Baily, Martin Neil (2007) 'Dollar Adjustment to Reduce the US Imbalance', unpublished manuscript, Peterson Institute for International Economics, Washington DC, February

Blejer, Mario (2007) Emerging Markets: Cyclical Upswing or a New Paradigm?, London: Bank of England

Chinn, Mensie David and Hiro, Ito (2006) Notes on the Calculation of the Chinn-Ito Financial Openness Variable, www.ssc.wisc.edu/mchinn

Eichengreen, Barry and Mody, Ashoka (1998) 'Interest Rates in the North and Capital Flows to the South: Is There a Missing Link?', International Finance 1: 35-58

Eichengreen, Barry and Yung Chul Park (2006) 'Global Imbalances and Emerging Markets', Conference on European and Asian Perspective on Global Imbalances, 13-14 July 2006, Beijing: AEEF

Fitch Ratings (2005) 'Assessing Bank Systemic Risk: A New Product', Criteria Report, New York: Fitch

Ghosh, Swati (2006) East Asian Finance, The Road to Robust Markets, Washington DC: World Bank

Goldstein, Morris and Turner, Philip (2004) Currency Mismatching in Emerging Economics, Stockholm: Institute for International Economics

IMD (2006) World Competitiveness Yearbook, Lausanne: IMD International

IMF (International Monetary Fund) (2006a) Global Financial Stability Report, Washington DC: IMF

IMF (International Monetary Fund) (2006b) IMF Handbook on Financial Sector Assessments, Washington DC: IMF

IMF (International Monetary Fund) (2006c) Regional Economic Outlook: Asia and Pacific, Washington DC: IMF

IMF (International Monetary Fund) (2006d) World Economic Outlook 2006, Washington DC: IMF International Financial Statistics (2006) Online database available at http://ifs.apdi.net/imf/logon.asp, Washington DC: International Monetary Fund Jeanne, Olivier and Rancière, Romain (2006) The Optimal Level of International Reserves for Emerging
Market Countries: Formulas and Applications, IMF Working Paper WP/06/229, Washington DC: International Monetary Fund (IMF)

Jeanne, Olivier and Wyplosz, Charles (2003) 'The International Lender of Last Resort: How Large Is Large Enough?', in M.P. Dooley and J.A. Frankel (eds), Managing Currency Crises in Emerging Markets, Chicago: University of Chicago Press Jeon, Jongkyou, Yonghyup Oh and Doo Yong Yang (2005) 'Financial Integration in East Asia', presentation paper at the workshop of ASEAN+3 Research Group titled 'Economic Integration in East Asia', Tokyo, 20 January

Kaplan, Ethan and Rodrik, Dani (2001) Did the Malaysian Capital Controls Work?, NBER Working Paper 8142, Cambridge MA: NBER

Kaufmann, Daniel; Kraay, Aart and Mastrussi, Massimo (2006) Governance Matters V: Governance Indicator for 1996-2005, Washington DC: World Bank

Kim, Soyoung; Jong-Wha Lee and Kwanho Shin (2005) 'Regional and Global Financial Integration in East Asia,' preliminary draft, Seoul: Economics Department, Korea University

Kose, M. Ayhan; Prasad, Eswae; Rogoff, Kenneth and Shang-Jin Wei (2006) Financial Globalisation: A Reappraisal, Washington DC: International Monetary Fund (IMF)

Lane, P.R. and Milesi-Feretti, G.M. (2006) The External Wealth of Nations Mark II: Revised and Extended Estimates for Foreign Assets and Liabilities, 1970-2004, IMF Working Paper 06/69, Washington DC: International Monetary Fund Lee, Jaewoo (2004) Insurance Value of International Reserves: An Option Pricing Approach, IMF Working Paper No. 04/175, Washington DC: International Monetary Fund (IMF)

Park, Yung Chul and Song, Chi-Young (2001) Institutional Investors, Trade Linkage, Macroeconomic Similarities and the Contagious Thai Crisis', The Journal of Japanese and International Economics 15.2: 199-224

Park, Yung Chul and Wyplosz, Charles (2004) 'Exchange Rate Arrangements in East Asia: Do They Matter?', in Yonghyup Oh, Deo Ryong Yoon and Thomas D. Willett (eds), Monetary and Exchange Rate Arrangements in East Asia, Seoul: Korea Institute for International Economic Policy: 129-60

Rodrik, Dani (2006) The Social Cost of Foreign Exchange Reserves, NBER Working Paper 11952, Cambridge MA: NBER 
Shin, Kwanho and Doo Yong Yang (2006) 'Trade and Financial Integration: Do They Reinforce Each Other?', Seoul Conference 'China and Emerging Asia: Reorganising the Global Economy', Seoul, Korea, 11-12 May

Shu, Haibin (2006) 'The Structure of Housing Finance Markets and House Prices in Asia,' Part 5 BIS Quarterly Review, Basel: BIS
The Economist (3 March 2005, 8 December 2005, 7 December 2006)

World Bank (2006) East Asia Update, Managing Through a Global Downturn, Washington DC: The World Bank 